\title{
Adenovirus-mediated SOCS3 gene transfer inhibits the growth and enhances the radiosensitivity of human non-small cell lung cancer cells
}

\author{
YU-CHING LIN ${ }^{1,2,6}$, CHIN-KUO LIN ${ }^{1,2,6}$, YING-HUANG TSAI ${ }^{1,4}$, HSU-HUEI WENG ${ }^{3,6}$, YA-CHIN LI ${ }^{1}$, \\ LIANG YOU ${ }^{8}$, JAN-KAN CHEN ${ }^{5}$, DAVID M. JABLONS ${ }^{8}$ and CHENG-TA YANG ${ }^{4,7}$ \\ ${ }^{1}$ Division of Pulmonary and Critical Care Medicine, Departments of ${ }^{2}$ Respiratory Care, and ${ }^{3}$ Diagnostic Radiology, \\ Chang Gung Memorial Hospital, Chiayi; Departments of ${ }^{4}$ Respiratory Care, and ${ }^{5}$ Physiology, College of Medicine, \\ Chang Gung University, Taoyuan; ${ }^{6}$ Chang Gung Institute of Technology, Chiayi; ${ }^{7}$ Department of Thoracic \\ Medicine, Chang Gung Memorial Hospital, Taipei, Taiwan, R.O.C.; ${ }^{8}$ Thoracic Oncology Laboratory, \\ Department of Surgery, University of California, San Francisco, CA 94115, USA
}

Received July 14, 2010; Accepted September 2, 2010

DOI: $10.3892 /$ or_00001024

\begin{abstract}
The Janus kinase-signal transducers and activators of transcription (JAK-STAT) pathway is one of the most important components of cytokine signaling cascades. JAK-STAT signaling pathway modulates various fundamental biological processes and cancer pathogenesis. JAK-STAT is controlled by negative regulators that include suppressors of cytokine signaling (SOCS) proteins. Failure of feedback suppression by SOCS proteins may result in activated JAK-STAT signaling. Methylation-mediated silencing of SOCS3 has been reported in non-small lung cancer (NSCLC) and other human cancers. In this study, we restored SOCS3 expression using adenovirus-mediated gene transfer in NSCLC cells. Infection with a SOCS3-expressing vector inhibited the growth of lung cancer cells, with or without SOCS3 expression, at 2-3 days after infection. The growth inhibition of lung cancer cells was associated with suppressing entry into the S-phase. Restoration of SOCS3 expression induced apoptosis of NSCLC cells that did not express SOCS3. In addition, over-expression of SOCS3 by adenoviral transfer enhanced the radiosensitivity of treated NSCLC cells. In conclusion, our findings may provide insights into the development of applications of SOCS3 gene therapy for lung cancer and, possibly, other human cancers.
\end{abstract}

Correspondence to: Dr Cheng-Ta Yang, Department of Thoracic Medicine, Chang Gung Memorial Hospital 199, Tung-Hwa North Road, Taipei 10507, Taiwan, R.O.C.

E-mail: yang1946@adm.cgmh.org.tw

Key words: Janus kinase-signal transducers and activators of transcription, SOCS3, adenovirus, gene therapy, radiotherapy, nonsmall cell lung cancer

\section{Introduction}

Suppressors of cytokine signaling (SOCS) proteins comprise a family of eight cytoplasmic proteins: cytokine-inducible SH2-domain-containing protein (CIS) and SOCS1-7 $(1,2)$. SOCS proteins contain a central $\mathrm{SH} 2$ domain, a conserved C-terminus (the SOCS box) and a unique N-terminus $(1,2)$. Expression of SOCS proteins can be stimulated by activating Janus kinase-signal transducer and activator of transcription (JAK-STAT) pathways. SOCS can inhibit JAK activity via a feedback loop by binding to both a cytokine receptor and JAK itself (3-5).

JAK-STAT pathway mediates cytokine signaling, which control immune functions, cell growth, differentiation and hematopoiesis (6). Aberrant activation of JAK-STAT pathway has been implicated in many human cancers. Constitutively activated JAK leads to persistent activation of STAT3. Constitutive activation of JAK2 was found in T-cell acute lymphoblastic leukemia of childhood (7). An activating somatic JAK2 mutation that encodes a V617F substitution, which promotes JAK2 catalytic activation and cytokine-independent signaling, was identified in the majority of patients with myeloproliferative neoplasms $(8,9)$. In addition, STAT3 is a well-known oncogene (10). Transfection with constitutively activated STAT3 results in tumorigenesis in nude mice (10). Constitutively active STAT3 has been found in various human cancers, including non-small cell lung cancer (NSCLC) (11-13).

Aberrant SOCS feedback inhibition of JAK-STAT signaling can also result in carcinogenesis. Abnormal STAT3 activation after SOCS3 genetic ablation has been demonstrated (14-16). In addition, deletion of the SOCS3 gene promoted hepatitis-induced hepatocarcinogenesis (17). Down-regulation of SOCS3 in both lung adenocarcinoma and squamous cell carcinoma was demonstrated by cDNA microarrays $(18,19)$. SOCS3 silencing by promoter hypermethylation with enhanced STAT3 activation has been reported in human NSCLC (11) and various other human 
cancers, including hepatocellular carcinoma, head and neck squamous cell carcinoma, cholangiocarcinoma, glioblastoma multiforme, myeloproliferative disorders and acute myeloid leukemia (20-25). For NSCLC, $80 \%$ of surgically resected specimens showed SOCS3 silencing due to promoter methylation (11). In contrast, exogenous SOCS3 could suppress growth $(11,26)$ and induce apoptosis of human lung cancer cells (11). Hence, exogenous SOCS3 may be a potential therapeutic modality for NSCLC.

Genotoxic agents, such as ionizing radiation, induce cell cycle arrest at the G1/S and G2/M checkpoints. This induced cell arrest allows cells to repair damaged DNA before entry into mitosis. STAT3 is a well-known key element for controlling the G1 to S cell cycle transition (27). Kim et al observed that phosphor-Stat $3 \mathrm{Tyr}^{705}$ levels were decreased in human umbilical vein endothelial cells (HUVECs) after irradiation, but not in breast cancer cells (28). Thus, uncontrolled STAT3 signaling antagonizes G1 arrest (29) and confers inherent radioresistance (30). Similarly, Sitko et al reported that SOCS3-deficient fibroblasts failed to undergo G1 arrest and accumulated in the G2/M phase after irradiation (29). Moreover, enhanced radiation-induced apoptosis of prostate cancer cells could be achieved with an antisense oligonucleotide of STAT3 (31). As a feedback inhibitor, overexpression of SOCS3 may enhance the radiosensitivity of cancer cells by inhibiting STAT3.

Therefore, we hypothesized that exogenous SOCS3 might play a role in treating NSCLC by inhibiting STAT3. We designed a SOCS-expressing adenoviral vector and studied the effects of exogenous SOCS3 on NSCLC cells by focusing on growth inhibition and susceptibility to irradiation.

\section{Materials and methods}

Cell lines and cell culture. Human NSCLC cell lines, NCIH460 (ATCC HTB-177), NCI-H838 (ATCC CRL-5844), NCI-A549 (ATCC CCL-185), NCI-H1703 (ATCC CRL5889), WI-38 (ATCC CCL-75) and 293 (CRL-1573), were purchased from the American Type Culture Collection (Manassas, VA, USA). H460 and A549 cells were cultured in Dulbecco's modified Eagle's medium (D-MEM) containing $10 \%$ fetal bovine serum (FBS). H1703 and H838 cells were cultured in RPMI-1640 complete medium containing $10 \%$ FBS. WI-38 cells were cultured in Eagle's minimal essential medium containing Earle's BSS, $2 \mathrm{mM}$ L-glutamine and $10 \%$ fetal bovine serum and was modified to contain $1 \mathrm{mM}$ sodium pyruvate, $0.1 \mathrm{mM}$ non-essential amino acids and $1.5 \mathrm{~g} / 1$ sodium bicarbonate. Two hundred and twenty-three cells were cultured in D-MEM containing $10 \%$ heat-inactivated horse serum. All cells were cultured at $37^{\circ} \mathrm{C}$ in a humid incubator with $5 \% \mathrm{CO}_{2}$.

Adenoviral vectors. A 579 base-pair fragment cDNA construct of human SOCS3 (11) was cloned into an adenoviral vector (AdEasy System) (32). Briefly, the SCOS3 complementary DNA was first cloned into a shuttle vector, pAdTrack-CMV, which contained cytomegalovirus promoters and a green fluorescent protein (GFP) gene. The resultant plasmid was then linearized by digesting with restriction endonuclease and was subsequently co-transformed into electrocompetent
BJ5183 cells with an adenoviral backbone plasmid, pAdEasy-1. Recombinants were selected for kanamycin resistance and recombination was confirmed by restriction endonuclease analysis. The linearized recombinant plasmid was then transfected into 293 cells (E1-transformed human embryonic kidney cells). The SOCS3 recombinant adenovirus Ad-SOCS3-GFP (AdSOCS3) was generated and identified by PCR of the cell culture supernatant. The control recombinant adenovirus Ad-GFP (AdCtrl), which was constructed with pAdTrack and pAdEasy-1, was used as a control in these experiments.

Western blotting. Approximately $1 \times 10^{6}$ cells were plated in $10-\mathrm{cm}$ dishes and incubated for $15 \mathrm{~h}$ at $37^{\circ} \mathrm{C}$ before infection. The cells were mock-infected or infected with either AdCtrl or AdSOCS3, each at a multiplicity of infection (MOI) of 100 , and incubated for $48 \mathrm{~h}$. Samples were washed twice with phosphate-buffered saline (PBS), scraped off the plates, and lysed in cell lysis buffer [50 mM Tris- $\mathrm{HCl}$ (pH 7.5), $150 \mathrm{mM} \mathrm{NaCl}, 1 \%$ Nonidet P-40, $0.5 \%$ sodium deoxycholate and $0.1 \%$ sodium dodecyl sulfate (SDS)]. Whole cell lysates were boiled, and protein concentrations were determined with the Bradford assay (Bio-Rad Laboratories, Hercules, CA, USA). Equal amounts of protein (20-40 $\mu \mathrm{g})$ were separated by SDS-polyacrylamide gel electrophoresis under reducing conditions in $4-15 \%$ linear gradient polyacrylamide gels. After the proteins were transferred onto PVDF membranes (Bio-Rad Laboratories), the membranes were blocked with 5\% non-fat milk and $0.2 \%$ Tween-20 in Tris-buffered saline (TBS-T) for $1 \mathrm{~h}$ at room temperature and then incubated with a primary antibody overnight at $4^{\circ} \mathrm{C}$. Membranes were washed in TBS-T for three 5-min periods. Primary antibodies for SOCS3 and $\gamma$-tubulin were purchased from Santa Cruz Biotechnology (Santa Cruz, CA, USA). Horseradish peroxidase-conjugated goat anti-mouse or donkey anti-goat antibody was used as a secondary antibody (Santa Cruz). Proteins were visualized with chemiluminescence luminal reagents (Santa Cruz).

Cytotoxicity assay. A total of $1 \times 10^{5}$ cells were seeded into 6-well culture plates and incubated for $15 \mathrm{~h}$ at $37^{\circ} \mathrm{C}$ before infection. Cells were then mock-infected or infected with AdCtrl or AdSOCS3 at different concentrations and incubated for an additional 3 days. Cells were collected after trypsinization and re-suspended in PBS. An equal volume of $0.4 \%$ trypan blue solution was added to the cell suspension. Viable cells were counted with a hemocytometer. All cell counts were done for triplicate samples.

Viability assay and growth curve. A total of $1 \times 10^{5}$ cells were plated into 6-well culture plates as described previously. Later, cells were mock-infected or infected with either AdCtrl or AdSOCS3 at 20 MOI and incubated for 7 days. Cells were collected and counted daily as mentioned in the section on the cytotoxicity assay. All cell counts were done for triplicate samples.

Cell cycle analysis and apoptosis assay. $\mathrm{H} 460$ cells $\left(1 \times 10^{6}\right)$ were plated in $10-\mathrm{cm}$ dishes and incubated for $15 \mathrm{~h}$ at $37^{\circ} \mathrm{C}$ before infection. Cells were then mock-infected or infected 
with either 50 MOI AdCtrl or AdSOCS3 and incubated for $48 \mathrm{~h}$. For cell cycle analysis, cells were collected after trypsinization, washed twice with PBS (sample buffer), and then fixed in ice-cold $70 \%$ ethanol overnight at $4^{\circ} \mathrm{C}$. Cells were then centrifuged for $5 \mathrm{~min}$ at $1500 \mathrm{rpm}$ at room temperature. After decanting the $70 \%$ ethanol without disturbing the pellets, the cells were treated with ribonuclease A $(100 \mathrm{U})$ for $15 \mathrm{~min}$ at $37^{\circ} \mathrm{C}$. The cells were then stained with propidium iodide $(50 \mathrm{mg} / \mathrm{ml})$ in sample buffer. Samples were analyzed by two-dimensional flow cytometry (Epics ALTRA; Beckman-Coulter, Fullerton, CA, USA) to detect both green fluorescent protein and propidium iodide. The cell cycle distribution was analyzed by Multicycle software for windows version 3.0 (Phoenix Flow Systems, San Diego, CA, USA). For apoptosis assays, H460 cells were treated with 50 and $100 \mathrm{MOI}$ of adenoviral vectors. After treatments for $48 \mathrm{~h}$, cells were collected as previously described for Western blotting. Primary antibody for full-length caspase-3 was from Cell Signal Technology (Danvers, MA, USA); primary antibody for cleaved caspase-3 was from Chemicon (Temecula, CA, USA). Full-length and cleaved caspase-3 were detected according to the manufacturer's instructions.

Irradiation. Cells ( $1 \times 10^{5} /$ well) were plated onto 6-well culture plates and incubated for $16 \mathrm{~h}$ at $37^{\circ} \mathrm{C}$ prior to infection. Subsequently, they were mock-infected or infected with either AdCtrl or AdSOCS3 at MOI of 10, 20 or 50. Fortyeight hours after infection, the cells were irradiated $(0,2,4$ or $8 \mathrm{~Gy}$ in a single fraction) with a $6-\mathrm{MeV}$ electron beam generated by a linear accelerator (Clinac 21EX; Varian, Palo Alto, CA, USA) at a dose rate of $300 \mathrm{cGy} / \mathrm{min}$. On day 3 after irradiation, triplicate cultures for each combination treatment were counted for viable cells.

Statistical analysis. Results are given as means \pm standard deviations (SD). Student's unpaired t-test was used to compare different treatments. Three-way analysis of variance (ANOVA) was used to compare the survival proportions and SDs at the different MOI levels (10, 20, and 50) and varying radiation doses for treating AdCtrl or AdSOCS3. Pairwise comparisons were made using Tukey HSD pair-wise comparisons. A p-value $<0.05$ was considered as statistically significant. Analyses used Stata statistical software version 10.1 (StataCorp., College Station, TX, USA).

\section{Results}

Expressions of exogenous SOCS3 in human NSCLC cell lines. To study the effects of exogenous SOCS3 expression in NSCLC cells, we constructed a CMV promoter-driven SOCS3-expressing adenoviral vector (AdSOCS3). We then infected NSCLC cells with either AdSOCS3 or a control vector (AdCtrl) for further analysis. The infection efficiency was monitored by GFP expression (Fig. 1A). After infection with AdSOCS3 for $48 \mathrm{~h}$, SOCS3 protein could be detected by Western blotting (Fig. 1B).

Exogenous SOCS3 expression inhibits lung cancer cell growth. Upon confirming the expression of exogenous SOCS3 using this approach, we first conducted a dose-
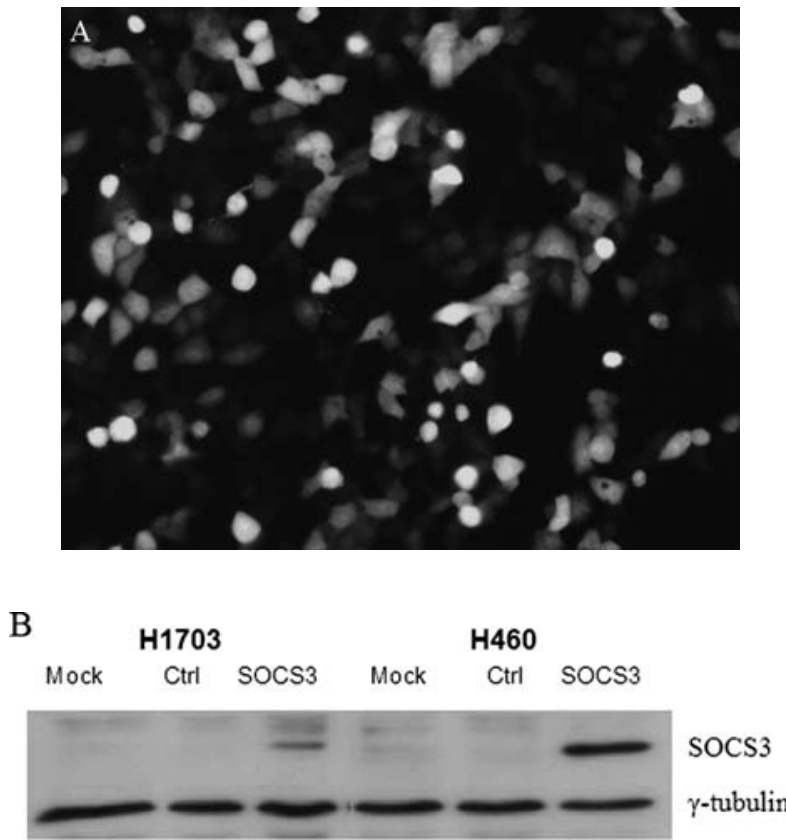

Figure 1. Infection with adenoviral vectors. (A) Cells were seeded and incubated for $15 \mathrm{~h}$ at $37^{\circ} \mathrm{C}$, mock-infected or infected with AdSOCS3 or AdCtrl, and incubated for additional 3 days. Fluorescence in $\mathrm{H} 460$ cells, $72 \mathrm{~h}$ after transfection with AdSOCS3. Original magnification, x200. (B) Cells were plated and incubated for $15 \mathrm{~h}$ at $37^{\circ} \mathrm{C}$ before infection. The cells were then mock infected or infected with either AdCtrl or AdSOCS3 (each at a multiplicity of infection of 100) and incubated for $48 \mathrm{~h}$. The cells then were harvested for Western blot analysis.

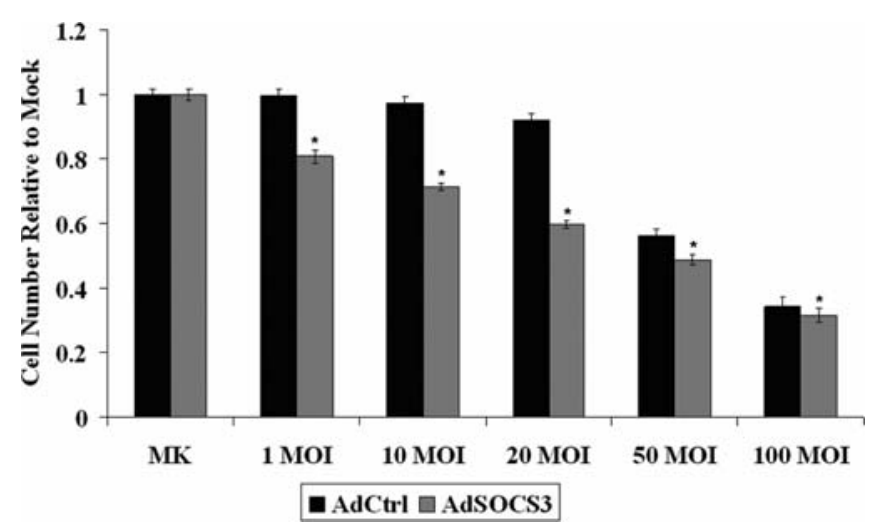

Figure 2. Cytotoxicity assay. Cells were plated in triplicate wells and incubated at $37^{\circ} \mathrm{C}$ for $15 \mathrm{~h}$ before infection. AdCtrl and AdSOCS3 were added at various concentrations and incubated for 7 days at $37^{\circ} \mathrm{C}$. Cells were collected after trypsinization and resuspended in PBS. An equal volume of $0.4 \%$ trypan blue solution was added to the cell suspension. Viable cells were then counted with a hemocytometer. All cell counts were done on triplicate samples. Data from H838 cell line were represented. The error bars represent standard deviation (SD). AdSOCS3 versus AdCtrl, MOI of $1, \mathrm{p}<0.001$; MOI of $10, \mathrm{p}<0.001$; MOI of $20, \mathrm{p}<0.001$; MOI of 50 , $\mathrm{p}=0.009$; MOI of $100, \mathrm{p}=0.264$. ${ }^{*} \mathrm{p}$-value $<0.05$, Student's t-test. Mock, mock infection; AdCtrl, infected with control AdCtrl viral vectors; AdSOCS3, infected with AdSOCS3 viral vectors.

titration study for the adenoviral vectors. Significant growth inhibition was found for cells that were infected with AdSOCS3 concentrations higher than 10 MOI in a dose-dependent manner. Exogenous SOCS3 expression suppressed the growth of cancer cells, irrespective of their 
Day 3

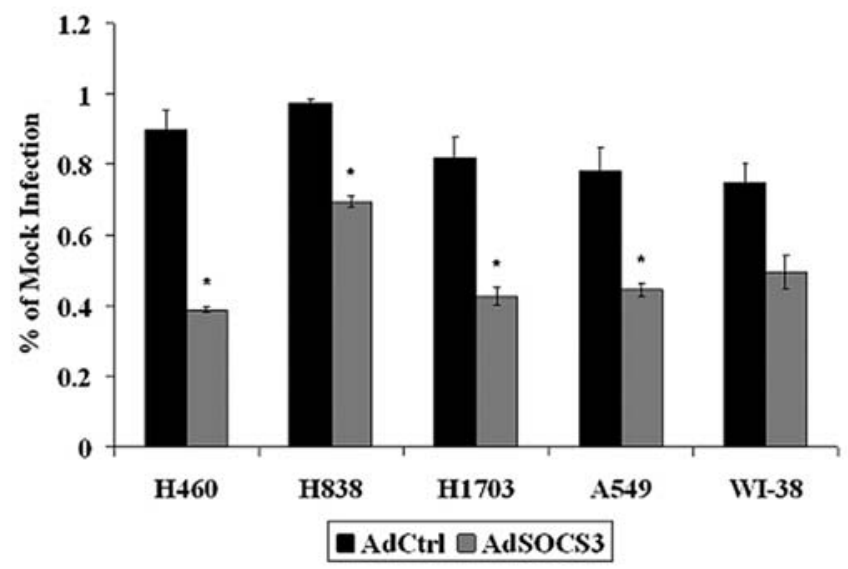

Day 7

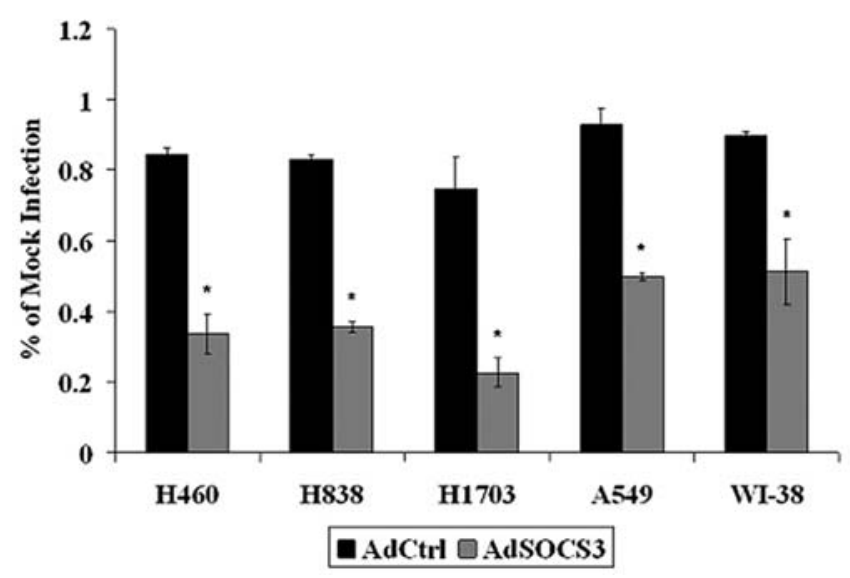

Figure 3. Viability after treatment with adenoviral vectors. Cells were seeded and incubated for $15 \mathrm{~h}$ at $37^{\circ} \mathrm{C}$, mock-infected or infected with AdCtrl or AdSOCS3 20 MOI, and incubated for additional 3 or 7 days. Cells were collected after trypsinization and suspended in PBS. An equal volume of $0.4 \%$ trypan blue solution was added to the cell suspension. Viable cells were then counted with a hemocytometer. All cell counts were done in triplicate. "p-value $<0.05$, Student's t-test, day $3,0.00379,<0.001,0.002$, 0.0083 and 0.0035 , respectively; day $7,0.0029,<0.001,0.00362,0.0027$ and 0.0176 , respectively. Mock, mock infection; AdCtrl, infected with control AdCtrl viral vectors; AdSOCS3, infected with AdSOCS3 viral vectors.

status for constitutive SOCS3 expression. However, significant AdCtrl toxicity was found for concentrations higher than 50 MOI. Hence, we chose 20 MOI for most of the experiments (Fig. 2). From growth curve studies, significant growth inhibition was found at days 2 or 3 and up to day 7 . Growth inhibition was also found for normal WI-38 cells treated with AdSOCS3 (Figs. 3 and 4).

Exogenous SOCS3 expression suppresses S-phase entry and induces apoptosis. In order to identify the mechanisms of growth inhibition that were induced by exogenous SOCS3 expression in lung cancer cells, cycle analysis was performed. After treatment with AdSOCS3 for 4 days, an increased sub-G1 fraction was found in $\mathrm{H} 460$, but not A549 cells: mock, AdCtrl, AdSOCS3 percentages at $96 \mathrm{~h}$ were $2.07,1.56,10.61$ and $1.79,0.52,0.81 \%$ for $\mathrm{H} 460$ and A549 cells, respectively (Fig. 5A). In addition, G1 arrest was observed for AdSOCS3-treated A549 cells: G1/S mock,
A $\quad$ H460

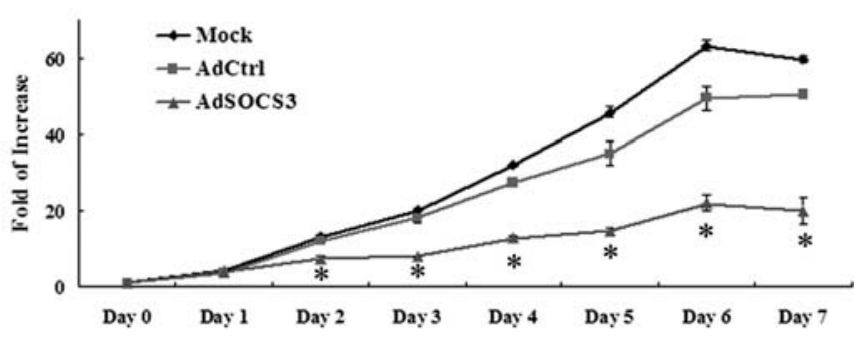

B

H1703

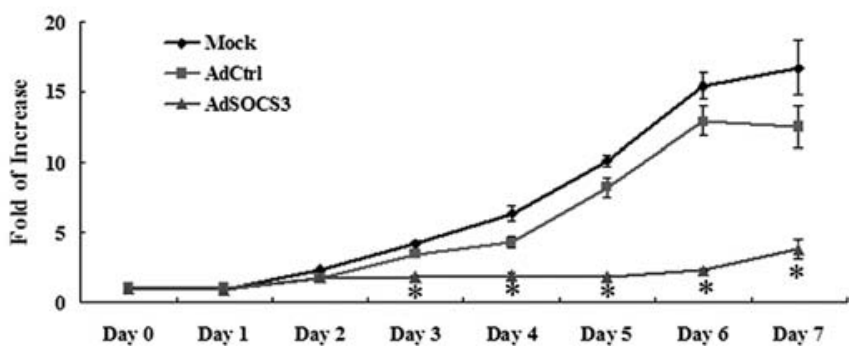

C

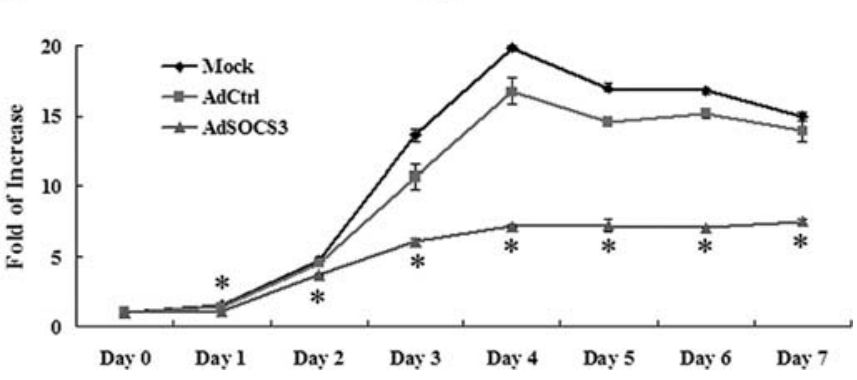

$\mathrm{D}$

H838

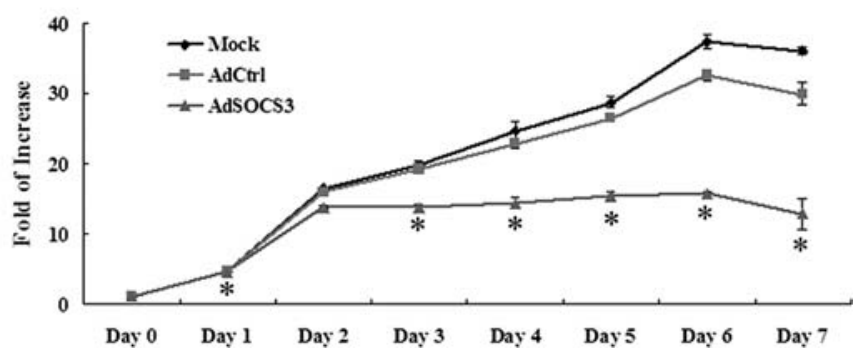

Figure 4. Growth inhibition after treatment with adenoviral vectors. (A) H460, (B) H1703, (C) A549, (D) H838 cells. Cells were seeded and incubated for $4 \mathrm{~h}$ at $37^{\circ} \mathrm{C}$, mock-infected or infected with AdCtrl or AdSOCS3, and incubated for additional 3 or 7 days. Cells were collected after trypsinization and suspended in PBS. An equal volume of $0.4 \%$ trypan blue solution was added to the cell suspension. Viable cells were then counted with a hemocytometer. All cell counts were done in triplicate. ${ }^{*} \mathrm{p}<0.05$, Student's t-test. Mock, mock infection; AdCtrl, infected with control AdCtrl viral vectors; AdSOCS3, infected with AdSOCS3 viral vectors.

AdCtrl, AdSOCS3 percentages at $72 \mathrm{~h}$ were $63.7 / 27.2 \%$, $70.7 / 20.7 \%, 85.8 / 6.0 \%$ (Fig. 5A). To further verify if apoptosis could be induced by exogenous SOCS3 expression in $\mathrm{H} 460$ cells, we analyzed the caspase-3 levels by Western blotting at $48 \mathrm{~h}$ after infection with viral vectors. Cleaved caspase- 3 increased in H460 cells treated with 
A
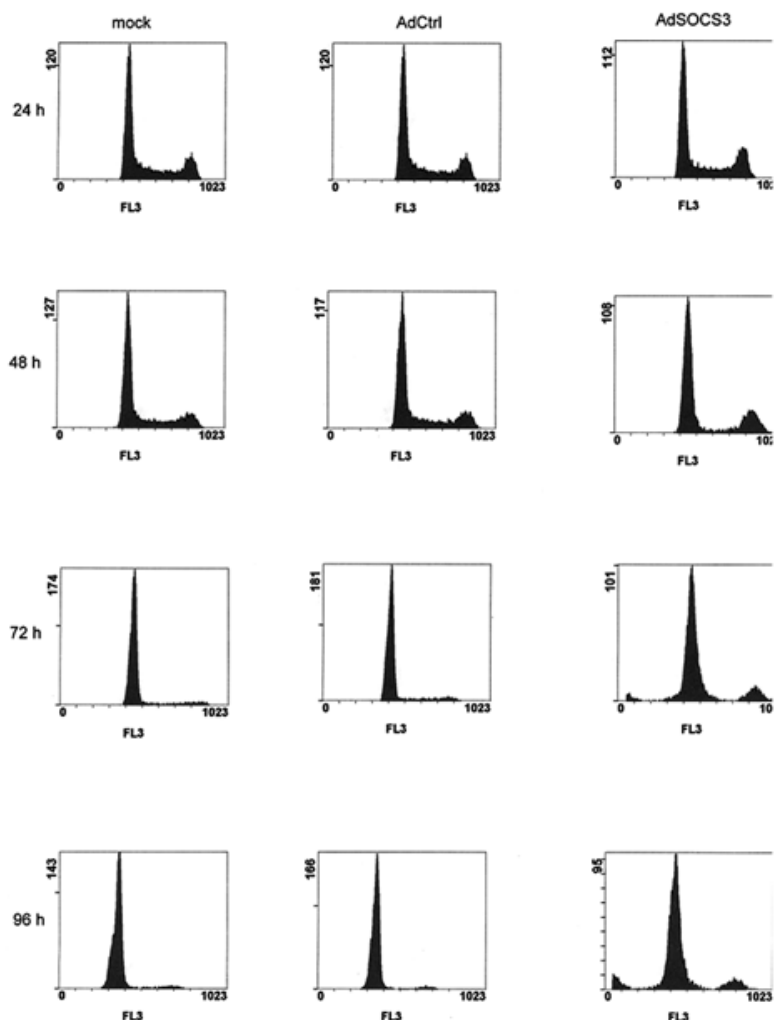

B

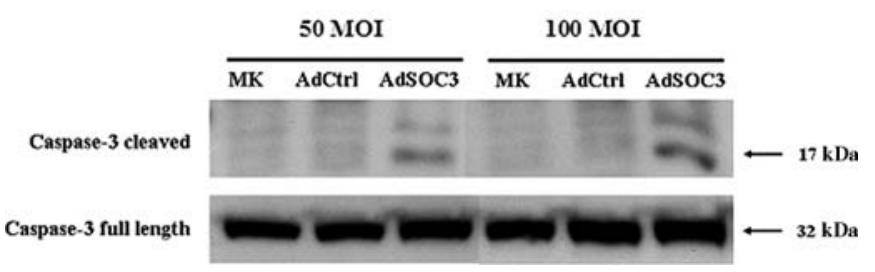

AdSOCS3, but not AdCtrl in a dose-dependent manner (Fig. 5B).

Exogenous SOCS3 expression increases the radiosensitivity of NSCLC cells. Because radioresistance can be reverted by STAT3 inhibition, we examined if exogenous SOCS3 could enhance the radiosensitivity of NSCLC cells. H460 and A549 cells were treated with AdCtrl or AdSOCS3 vectors at 10,20 and 50 MOI. The culture medium was used as mock infection. Cells were subsequently treated with varying radiation doses $(0,2,4,8 \mathrm{~Gy})$ at $48 \mathrm{~h}$ after infection. Survival proportions for both cell lines after radiation showed dose-dependent patterns, irrespective of the vectors and concentrations of the infecting vectors (three-way ANOVA, $\mathrm{p}<0.05$ in both comparisons; Fig. 6). For these vectors, AdSOCS3 inhibited cancer cell growth to a greater extent than did AdCtrl, regardless of the vector concentrations or the radiation doses $(\mathrm{p}<0.05)$. There was no difference in the survival proportions for cells that were treated with 10 or 20 MOI AdCtrl $(p>0.05)$. When combined with radiation, a higher concentration of AdSOCS3 resulted in a lower survival

\section{A549}
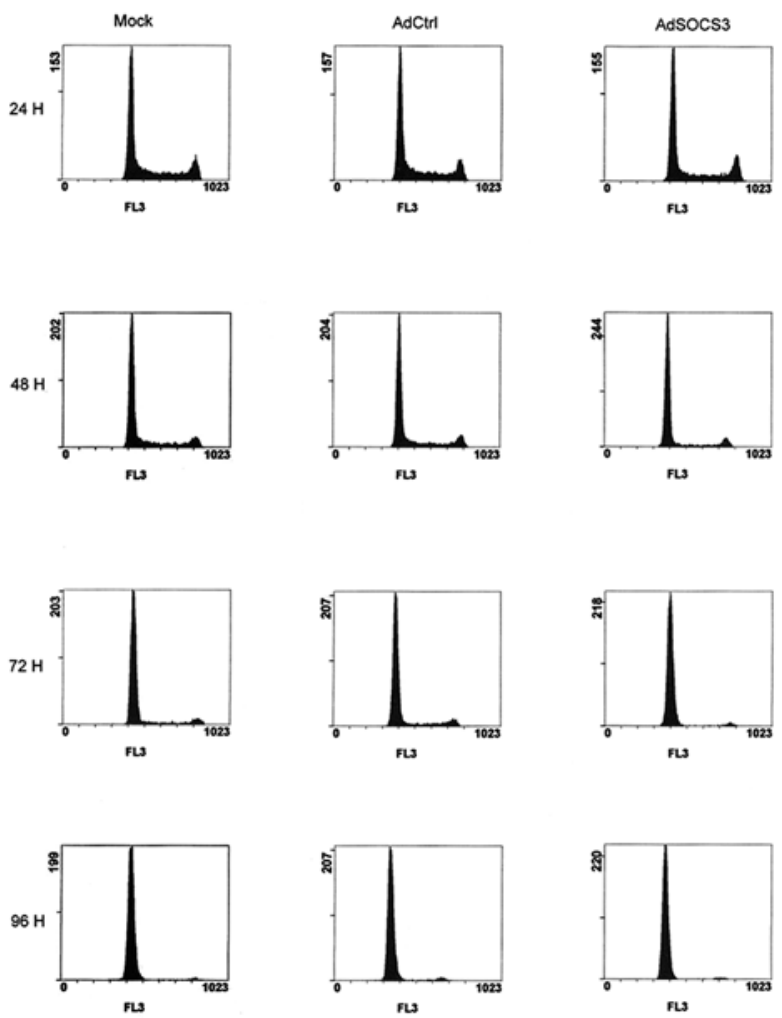

Figure 5. Exogenous SOCS3-induced apoptosis. (A) Cell cycle analysis $\mathrm{H} 460$ and A549 cells were plated and incubated for $15 \mathrm{~h}$ at $37^{\circ} \mathrm{C}$, then mock infected or infected with either AdCtrl or AdSOCS3, and incubated for additional $120 \mathrm{~h}$. The cells were collected after trypsinization, washed twice with 1X PBS (sample buffer), and then fixed in ice-cold $70 \%$ ethanol overnight at $4^{\circ} \mathrm{C}$. Cells were then centrifuged $5 \mathrm{~min}$ at $1500 \mathrm{rpm}$ at room temperature. After decanting the $70 \%$ ethanol without disturbing the pellet, we stained the cells with propidium iodide $(50 \mathrm{mg} / \mathrm{ml})$ and ribonuclease A (100 U/ml) in sample buffer. Samples were analyzed by two-dimensional flow cytometry to detect both green fluorescent protein and propidium iodide. The cell cycle distribution was determined by the cell cycle analysis software. (B) Cleaved caspase- 3 increased in H460 cells after infection with 50 or 100 MOI of AdSOCS3 for 48 h (Western blotting). MK or Mock, mock infection; AdCtrl, infected with control AdCtrl viral vectors; AdSOCS3, infected with AdSOCS3 viral vectors.

proportion for $\mathrm{H} 460$ cells, but not A549 cells $(\mathrm{p}<0.05$ and $\mathrm{p}>0.05$, respectively). Hence, exogenous SOCS3 expression enhanced the radiosensitivity of $\mathrm{H} 460$ cells. We did not analyze the data for $50 \mathrm{MOI}$ AdSOCS3, as this combination was too toxic for the cells (data not shown).

\section{Discussion}

A growing number of reports have shown that JAK-STAT pathways play important roles in oncogenesis. Constitutively active JAK2 was reported in human leukemia (7). Similarly, constitutive activation of STAT3, a substrate of JAK2, has been found in various human cancers $(11,33-35)$. Loss of JAK-STAT feedback inhibition can also lead to constitutively activated JAK-STAT signaling. Methylation-mediated silencing of SOCS3 has been reported in lung, liver and head and neck cancers $(11,20,21)$. 

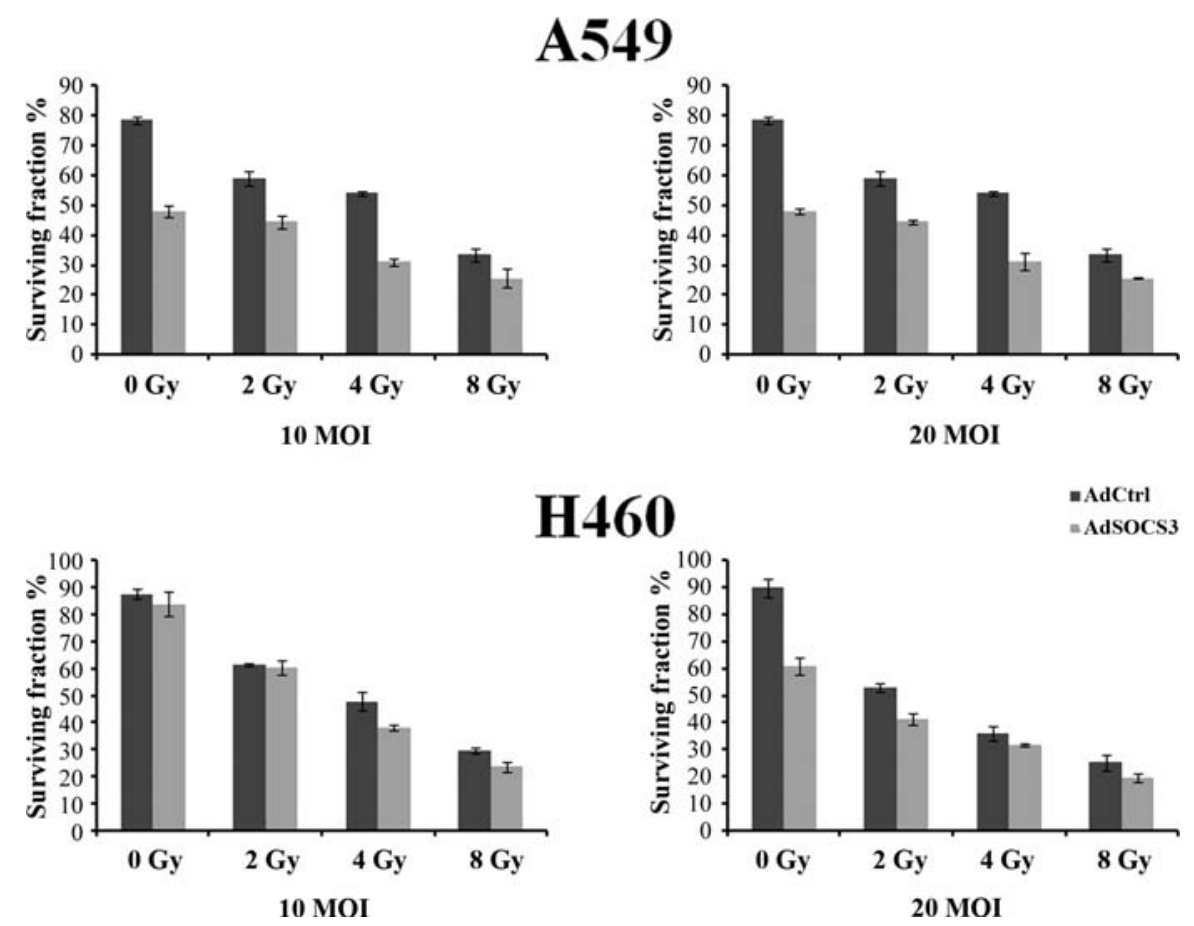

H460

- AdCtrl

$=$ AdSOCS3

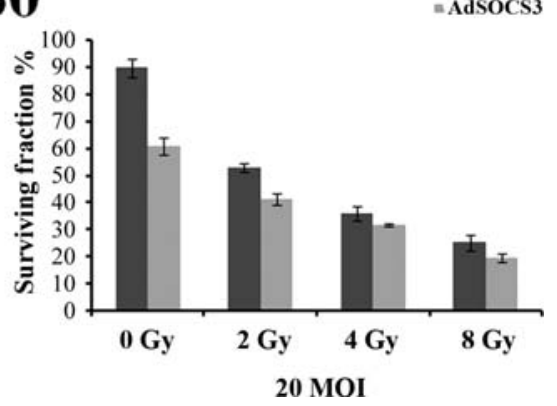

Figure 6. A549 and H460 cells were treated with AdCtrl or AdSOCS3 at MOI of 10 and 20. The culture medium alone was used for mock infection. These cells were subsequently treated with radiation at $0,2,4$, or 8 Gy $48 \mathrm{~h}$ after infection. Triplet cultures for each combination treatment were counted for the detection of any viable cells on day 3 after the radiation, i.e., day 5 after infection. Data for MOI 50 are not shown due to the too high toxicity when combining exogenous SOCS3 with irradiation.

Hence, it is a rational approach to restore SOCS3 expression in cancer cells by SOCS3 silencing. Restoration of SOCS3 using non-viral gene transfer in lung cancer cells with methylation-mediated SOCS3 silencing decreased phosphorylated STAT3 and led to growth suppression and apoptosis of cancer cells (11). Therefore, we studied SOCS3 gene therapy for lung cancer by constructing a SOCS3 expression adenoviral vector.

The application of an adenovirus for cancer therapy can be traced back to the 1950s when a wild-type adenovirus was used to treat cervical cancer (36). Adenoviral vectors are valuable in the development of novel anti-cancer treatments due to their high infectivity, cytotoxicity and immunogenicity (37). Adenovirus-based vectors are currently the most widely used platform for cancer gene therapy where temporary gene expression is beneficial (38). Using the AdEasy system (32), we constructed adenoviral vectors carrying $\mathrm{p} 14^{\mathrm{ARF}}$ or $\mathrm{p} 16^{\mathrm{INK} 4 \mathrm{~A}}$ in previous cancer gene therapy studies $(39,40)$.

$\mathrm{He}$ at al reported that SOCS3 was silenced in $\mathrm{H} 460$ cells due to hypermethylation of its promoter region and that there was no methylation of the SOCS3 promoter in A549 cells (11). Likewise, $77.8 \%$ (14/18) of primary lung cancer specimens showed methylation of the SOCS3 promoter region. In contrast, a recent study failed to detect methylation of the SOCS3 promoter region by MethyLight for matched lung cancer and non-cancerous tissues (41). Another report using fluorescence-based real-time MSP found SOCS3 methylation in 5\% (2/40) of primary lung cancer tissues (42). These inconsistencies regarding the methylation status of the SOCS3 promoter may be due to the different methods used.
However, in this study, exogenous SOCS3 expression induced growth inhibition in all lung cell lines, irrespective of their status for constitutive SOCS3 expression. There was a significant growth inhibition by 2-3 days after AdSOCS3 infection. Nevertheless, the growth rate of normal cells was also suppressed by AdSOCS3, although to a lesser level.

STAT3 is an oncogene that can regulate cell cycle progression and prevent apoptosis (10). STAT3 controls the $\mathrm{G} 1$ to $\mathrm{S}$ phase cell-cycle transition via the up-regulation of cyclins and concomitant down-regulation of p21 and p27 $(27,29)$. Selective inhibition of STAT3 by dominantnegative STAT3 induced apoptosis, G1 cell cycle arrest and reduced $S$ phase in anaplastic large cell lymphoma (43). Inhibition of the JAK-STAT3 pathway also resulted in G2 arrest $(44,45)$. As reported previously, inhibition of STAT3 with an anti-sense oligonucleotide induced activated caspase- 3 in nearly $88 \%$ of prostate cancer cells (46). In this study, exogenous SOCS3 suppressed S-phase entry in A549 cells. Interestingly, SOCS3 overexpression in H460 cells led to an increased sub-G1 population and cleaved caspase- 3 in a dose-response manner. Our findings are in agreement with the results of STAT3 inhibition. Hence, exogenous SOCS3 expression may suppress S-phase entry and induce apoptosis by feedback inhibition of STAT3. However, ectopic SOCS3 expression may exert its effects not only through negative regulation of STAT3.

The suppression of S-phase entry and induction of apoptosis in this study were induced at higher AdSOCS3 concentrations. This suggests that exogenous SOCS3 at lower concentrations may suppress lung cancer cell growth by mechanisms other than the induction of cell cycle arrest and apoptosis. However, at higher concentrations, the trans- 
ferred gene or the vector itself may induce undesirable toxicities. Nevertheless, cell cycle arrest and apoptosis induction were not found in cancer cells that were infected with higher concentrations of the empty vector AdCtrl. We further tested the effects of combined exogenous SOCS3 and irradiation on NSCLC cells. Our results suggest that exogenous SOCS3 can enhance the radiosensitivity of NSCLC cells.

In this study, we successfully showed that exogenous SOCS3 can suppress lung cell growth, even for those cells that express SOCS3. Although the inherent toxicity of adenoviral vectors and their cytotoxicity for normal cells are major concerns for gene therapy, advances have been achieved in developing more selective, safer and effective adenoviral vectors in recent years (38). In conclusion, our results indicate the potential of applying SOCS3 gene therapy not only to lung cancer, but also other human cancers.

\section{Acknowledgements}

This study was supported by grant No. 93-2320-B-182-034 from the National Science Council, Taiwan, R.O.C. to C.T.Y. and Chang Gung Memorial Hospital (CMRPG63009) to Y.C.L.

\section{References}

1. Hilton DJ: Negative regulators of cytokine signal transduction. Cell Mol Life Sci 55: 1568-1577, 1999

2. O'Shea JJ, Gadina M and Schreiber RD: Cytokine signaling in 2002: new surprises in the Jak/Stat pathway. Cell 109 (Suppl.): S121-S131, 2002.

3. Leonard WJ and O'Shea JJ: Jaks and STATs: biological implications. Annu Rev Immunol 16: 293-322, 1998.

4. Yasukawa H, Misawa H, Sakamoto H, Masuhara M, Sasaki A, Wakioka T, Ohtsuka S, Imaizumi T, Matsuda T, Ihle JN and Yoshimura A: The JAK-binding protein JAB inhibits Janus tyrosine kinase activity through binding in the activation loop. EMBO J 18: 1309-1320, 1999

5. Nicholson SE, De Souza D, Fabri LJ, Corbin J, Willson TA, Zhang JG, Silva A, Asimakis M, Farley A, Nash AD, Metcalf D, Hilton DJ, Nicola NA and Baca M: Suppressor of cytokine signaling-3 preferentially binds to the SHP-2-binding site on the shared cytokine receptor subunit gp130. Proc Natl Acad Sci USA 97: 6493-6498, 2000.

6. Cooney RN: Suppressors of cytokine signaling (SOCS) inhibitors of the JAK/STAT pathway. Shock 17: 83-90, 2002.

7. Lacronique V, Boureux A, Valle VD, Poirel H, Quang CT Mauchauffe M, Berthou C, Lessard M, Berger R, Ghysdael J and Bernard OA: A TEL-JAK2 fusion protein with constitutive kinase activity in human leukemia. Science 278: 1309-1312, 1997.

8. Baxter EJ, Scott LM, Campbell PJ, East C, Fourouclas N, Swanton S, Vassiliou GS, Bench AJ, Boyd EM, Curtin N, Scott MA, Erber WN and Green AR: Acquired mutation of the tyrosine kinase JAK2 in human myeloproliferative disorders. Lancet 365: 1054-1061, 2005

9. Kralovics R, Passamonti F, Buser AS, Teo SS, Tiedt R, Passweg JR, Tichelli A, Cazzola M and Skoda RC: A gainof-function mutation of JAK2 in myeloproliferative disorders. N Engl J Med 352: 1779-1790, 2005

10. Bromberg JF, Wrzeszczynska MH, Devgan G, Zhao Y, Pestell RG, Albanese C and Darnell JE Jr: Stat3 as an oncogene. Cell 98: 295-303, 1999

11. He B, You L, Uematsu K, Zang K, Xu Z, Lee AY, Costello JF, McCormick F and Jablons DM: SOCS-3 is frequently silenced by hypermethylation and suppresses cell growth in human lung cancer. Proc Natl Acad Sci USA 100: 14133-14138, 2003.

12. Song L, Turkson J, Karras JG, Jove R and Haura EB: Activation of Stat 3 by receptor tyrosine kinases and cytokines regulates survival in human non-small cell carcinoma cells. Oncogene 22: 4150-4165, 2003
13. Hodge DR, Hurt EM and Farrar WL: The role of IL-6 and STAT3 in inflammation and cancer. Eur J Cancer 41: 2502-2512, 2005.

14. Croker BA, Krebs DL, Zhang JG, Wormald S, Willson TA, Stanley EG, Robb L, Greenhalgh CJ, Forster I, Clausen BE, Nicola NA, Metcalf D, Hilton DJ, Roberts AW and Alexander WS: SOCS3 negatively regulates IL-6 signaling in vivo. Nat Immunol 4: 540-545, 2003 .

15. Lang R, Pauleau AL, Parganas E, Takahashi Y, Mages J, Ihle JN, Rutschman R and Murray PJ: SOCS3 regulates the plasticity of gp130 signaling. Nat Immunol 4: 546-550, 2003.

16. Yasukawa H, Ohishi M, Mori H, Murakami M, Chinen T, Aki D, Hanada T, Takeda K, Akira S, Hoshijima M, Hirano T, Chien KR and Yoshimura A: IL-6 induces an anti-inflammatory response in the absence of SOCS3 in macrophages. Nat Immunol 4: 551-556, 2003

17. Ogata H, Kobayashi T, Chinen T, Takaki H, Sanada T, Minoda Y, Koga K, Takaesu G, Maehara Y, Iida M and Yoshimura A: Deletion of the SOCS3 gene in liver parenchymal cells promotes hepatitis-induced hepatocarcinogenesis. Gastroenterology 131: 179-193, 2006.

18. Wikman H, Kettunen E, Seppanen JK, Karjalainen A, Hollmen J, Anttila $S$ and Knuutila S: Identification of differentially expressed genes in pulmonary adenocarcinoma by using cDNA array. Oncogene 21: 5804-5813, 2002

19. Kettunen E, Anttila S, Seppanen JK, Karjalainen A, Edgren H Lindstrom I, Salovaara R, Nissen AM, Salo J, Mattson K, Hollmen J, Knuutila S and Wikman H: Differentially expressed genes in non-small cell lung cancer: expression profiling of cancer-related genes in squamous cell lung cancer. Cancer Genet Cytogenet 149: 98-106, 2004.

20. Niwa Y, Kanda H, Shikauchi Y, Saiura A, Matsubara K, Kitagawa T, Yamamoto J, Kubo T and Yoshikawa H: Methylation silencing of SOCS-3 promotes cell growth and migration by enhancing JAK/STAT and FAK signalings in human hepatocellular carcinoma. Oncogene 24: 6406-6417, 2005.

21. Weber A, Hengge UR, Bardenheuer W, Tischoff I, Sommerer F, Markwarth A, Dietz A, Wittekind C and Tannapfel A: SOCS-3 is frequently methylated in head and neck squamous cell carcinoma and its precursor lesions and causes growth inhibition. Oncogene 24: 6699-6708, 2005

22. Isomoto H, Mott JL, Kobayashi S, Werneburg NW, Bronk SF, Haan S and Gores GJ: Sustained IL-6/STAT-3 signaling in cholangiocarcinoma cells due to SOCS-3 epigenetic silencing. Gastroenterology 132: 384-396, 2007

23. Martini M, Pallini R, Luongo G, Cenci T, Lucantoni C and Larocca LM: Prognostic relevance of SOCS3 hypermethylation in patients with glioblastoma multiforme. Int J Cancer 123: 2955-2960, 2008

24. Fourouclas N, Li J, Gilby DC, Campbell PJ, Beer PA, Boyd EM, Goodeve AC, Bareford D, Harrison CN, Reilly JT, Green AR and Bench AJ: Methylation of the suppressor of cytokine signaling 3 gene (SOCS3) in myeloproliferative disorders. Haematologica 93: 1635-1644, 2008.

25. Zhou J, Bi C, Janakakumara JV, Liu SC, Chng WJ, Tay KG, Poon LF, Xie Z, Palaniyandi S, Yu H, Glaser KB, Albert DH, Davidsen SK and Chen CS: Enhanced activation of STAT pathways and overexpression of survivin confer resistance to FLT3 inhibitors and could be therapeutic targets in AML. Blood 113: 4052-4062, 2009.

26. Ogata Y, Osaki T, Naka T, Iwahori K, Furukawa M, Nagatomo I, Kijima T, Kumagai T, Yoshida M, Tachibana I and Kawase I: Overexpression of PIAS3 suppresses cell growth and restores the drug sensitivity of human lung cancer cells in association with PI3-K/Akt inactivation. Neoplasia 8: 817-825, 2006.

27. Fukada T, Ohtani T, Yoshida Y, Shirogane T, Nishida K, Nakajima K, Hibi M and Hirano T: STAT3 orchestrates contradictory signals in cytokine-induced G1 to $\mathrm{S}$ cell-cycle transition. EMBO J 17: 6670-6677, 1998.

28. Kim KW, Mutter RW, Cao C, Albert JM, Shinohara ET, Sekhar KR and Lu B: Inhibition of signal transducer and activator of transcription 3 activity results in down-regulation of Survivin following irradiation. Mol Cancer Ther 5: 2659-2665, 2006.

29. Sitko JC, Yeh B, Kim M, Zhou H, Takaesu G, Yoshimura A, McBride WH, Jewett A, Jamieson CA and Cacalano NA: SOCS3 regulates p21 expression and cell cycle arrest in response to DNA damage. Cell Signal 20: 2221-2230, 2008 . 
30. Otero DC, Poli V, David M and Rickert RC: Cutting edge: inherent and acquired resistance to radiation-induced apoptosis in B cells: a pivotal role for STAT3. J Immunol 177: 6593-6597, 2006.

31. Calvin DP, Nam S, Buettner R, Sekharam M, Torres-Roca J and Jove R: Inhibition of STAT3 activity with STAT3 antisense oligonucleotide (STAT3-ASO) enhances radiation-induced apoptosis in DU145 prostate cancer cells. Int J Radiat Oncol Biol Phys 57: S297, 2003

32. He TC, Zhou S, da Costa LT, Yu J, Kinzler KW and Vogelstein B: A simplified system for generating recombinant adenoviruses. Proc Natl Acad Sci USA 95: 2509-2514, 1998.

33. Catlett-Falcone R, Landowski TH, Oshiro MM, Turkson J, Levitzki A, Savino R, Ciliberto G, Moscinski L, FernandezLuna JL, Nunez G, Dalton WS and Jove R: Constitutive activation of Stat 3 signaling confers resistance to apoptosis in human U266 myeloma cells. Immunity 10: 105-115, 1999.

34. Grandis JR, Drenning SD, Chakraborty A, Zhou MY, Zeng Q, Pitt AS and Tweardy DJ: Requirement of Stat3 but not Stat activation for epidermal growth factor receptor- mediated cell growth in vitro. J Clin Invest 102: 1385-1392, 1998.

35. Li L and Shaw PE: Autocrine-mediated activation of STAT3 correlates with cell proliferation in breast carcinoma lines. J Biol Chem 277: 17397-17405, 2002.

36. Huebner RJ, Rowe WP, Schatten WE, Smith RR and Thomas LB: Studies on the use of viruses in the treatment of carcinoma of the cervix. Cancer 9: 1211-1218, 1956.

37. Zhang WW: Development and application of adenoviral vectors for gene therapy of cancer. Cancer Gene Ther 6: 113-138, 1999.

38. Glasgow JN, Everts M and Curiel DT: Transductional targeting of adenovirus vectors for gene therapy. Cancer Gene Ther 13: 830-844, 2006

39. Yang CT, You L, Yeh CC, Chang JW, Zhang F, McCormick F and Jablons DM: Adenovirus-mediated p14(ARF) gene transfer in human mesothelioma cells. J Natl Cancer Inst 92: 636-641, 2000
40. Yang B, Guo M, Herman JG and Clark DP: Aberrant promoter methylation profiles of tumor suppressor genes in hepatocellular carcinoma. Am J Pathol 163: 1101-1107, 2003.

41. Feng Q, Hawes SE, Stern JE, Wiens L, Lu H, Dong ZM, Jordan CD, Kiviat NB and Vesselle H: DNA methylation in tumor and matched normal tissues from non-small cell lung cancer patients. Cancer Epidemiol Biomarkers Prev 17: 645-654, 2008.

42. Shivapurkar N, Stastny V, Suzuki M, Wistuba, II, Li L, Zheng Y, Feng Z, Hol B, Prinsen C, Thunnissen FB and Gazdar AF: Application of a methylation gene panel by quantitative PCR for lung cancers. Cancer Lett 247: 56-71, 2007.

43. Amin HM, McDonnell TJ, Ma Y, Lin Q, Fujio Y, Kunisada K, Leventaki V, Das P, Rassidakis GZ, Cutler C, Medeiros LJ and Lai R: Selective inhibition of STAT3 induces apoptosis and $\mathrm{G}(1)$ cell cycle arrest in ALK-positive anaplastic large cell lymphoma. Oncogene 23: 5426-5434, 2004.

44. Xiong H, Chen ZF, Liang QC, Du W, Chen HM, Su WY, Chen GQ, Han ZG and Fang JY: Inhibition of DNA methyltransferase induces G2 cell cycle arrest and apoptosis in human colorectal cancer cells via inhibition of JAK2/STAT3/STAT5 signaling. J Cell Mol Med 13: 3668-3679, 2009.

45. Ma J, Ye L, Da M and Wang X: Heavy ion irradiation increases apoptosis and STAT-3 expression, led to the cells arrested at $\mathrm{G} 2 / \mathrm{M}$ phase in human hepatoma SMMC-7721 cells. Mol Cell Biochem 328: 17-23, 2009.

46. Barton BE, Karras JG, Murphy TF, Barton A and Huang HF: Signal transducer and activator of transcription 3 (STAT3) activation in prostate cancer: direct STAT3 inhibition induces apoptosis in prostate cancer lines. Mol Cancer Ther 3: 11-20, 2004. 